Journal of Nepal Geological Society, 2019, vol. 59, pp. 89-94

DOI: https://doi.org/103126/jngs.v59i0.24994

\title{
Topographical and geological factors on gully-type debris flow in Malai River catchment, Siwaliks, Nepal
}

\author{
*Bharat Prasad Bhandari ${ }^{1}$ and Subodh Dhakal ${ }^{2}$ \\ ${ }^{1}$ Central Department of Environment Science, Tribhuvan University, Kirtipur \\ ${ }^{2}$ Department of Geology, Trichandra Multiple Campus, Tribhuvan University, \\ *Corresponding author: bbhandari@cdes.edu.np
}

\begin{abstract}
The Siwalik hill of Nepal lies in between the two major thrusts; Main boundary Thrust and Main Frontal Thrust. Thrusting and continuous erosion of material from surface causes several landslides and debris flow problem in the Siwalik region. Debris flow commonly occurs after landslide during heavy rainfall in the steep slope. This paper described about the topographical and geological controls on debris flow occurring in gullies in the Siwaliks of the Malai River catchment of mid-Western Nepal. The length of gully, length of debris channel, area of debris channel, area of catchment of debris flow, area of gully without debris flow were found using Google earth pro, a free version online database. Similarly, a form factor (F), average gradient of stream, slope area ratio and a topographical factor $(\mathrm{T})$ were calculated. Lithology and geological structure were studied in the field. The relation between each factor was identified.

Gully having larger debris flow event had $\mathrm{T}$ value greater than 0.01 and that having small debris flow event had $\mathrm{T}$ value less than 0.01. Gully without debris flow had T value less than 0.001 . Gully having debris flow had F more than 0.1 and that free from debris flow had F less than 0.1. Both topograohic and form factors were found greater than 0.1 at the hanging wall of the Malai Thrust, where large size debris flows were encountered. The T and F values obtained from the Middle and Upper Siwaliks were greater than 0.1. The number of debris flow events and large debris flows were found high the in the Middle and the Upper Siwaliks, and hanging wall of the Malai Thrust.
\end{abstract}

Keywords: Debris flow, Topographical factors, Gully-type debris flow, Malai Thrust, Siwaliks

Paper Received: 5 Apr 2019

Paper Accepted: 6th Jun 2019

\section{INTRODUCTION}

Debris flow is defined as a flow of mixture of sediment and water in a way such that it acts as a flow of continuous fluid driven by gravity. It achieves large movement from the enlarged void space saturated with water or slurry (Takahashi, 2007). Debris flow is a flood in mountain region that carries a bulk load with increased amount of sediment that leads it to change into viscous mass comprising of water, soil, sand, gravel, rock block and wood mixture flowing like lava into a valley (Stiny 1910). Gully-type debris flow is very common in the Siwalik Hills of Nepal. The Siwalik hills of Nepal lie in between the Terai and the Lesser Himalaya. Due to an active thrust and continuous erosion of material from the surface in rainy season, several landslide and debris flow in the Siwalik region occur. The debris flows commonly occur after landslide during heavy rainfall in the steep slope and such debris flows constrained in a narrow steep channel, therefore are considered gully-type debris flows, which are different from the hill slope debris flow (Vandine, 1985). The gully-type debris flows are triggered by flash flood during heavy rainfall (Kean et al., 2013). During flooding in the steep gully, the high-speed runoff causes erosion on the bank and washes away the eroded materials.
Various researchers have studied about the gully-type debris flow mechanism in the past (Hua-yong, 2015; Mei, 2018; Huang, 2019). Topography, geology and hydrology are three factors playing a major role in the formation of ordinary gullytype debris flow (Liu et al, 2009). The major responsible topographical factors include channel length, slope angle, slope curvature, form factors and elevation different (Lin et al., 2002; Lan et al., 2004; Ranjan et al., 2004; Catani et al., 2005; Chang and Chao 2006; Chang 2007; Lu et al., 2007; Lee and Pradhan 2007; Chang and Chien 2007; Tiranti et al., 2008; Tunusluoglu et al., 2008; Akgun et al., 2008). The formation mechanism of the triggered debris flows is the runoff-induced mechanism. Topography has influence on the formation of debris flows in gullies with almost identical hydrological and geological conditions (Li et al., 2015). Various factors are responsible for the occurrence of debris flow but this paper aims to relate debris flow occurrence due to topographic and geologic factors.

\section{STUDY AREA}

The Malai River watershed is located in the west of Tulsipur, Dang District of Nepal, and flows $25 \mathrm{~km}$ SE to NW, almost parallel to the Babai River that falls in the Siwalik zone 


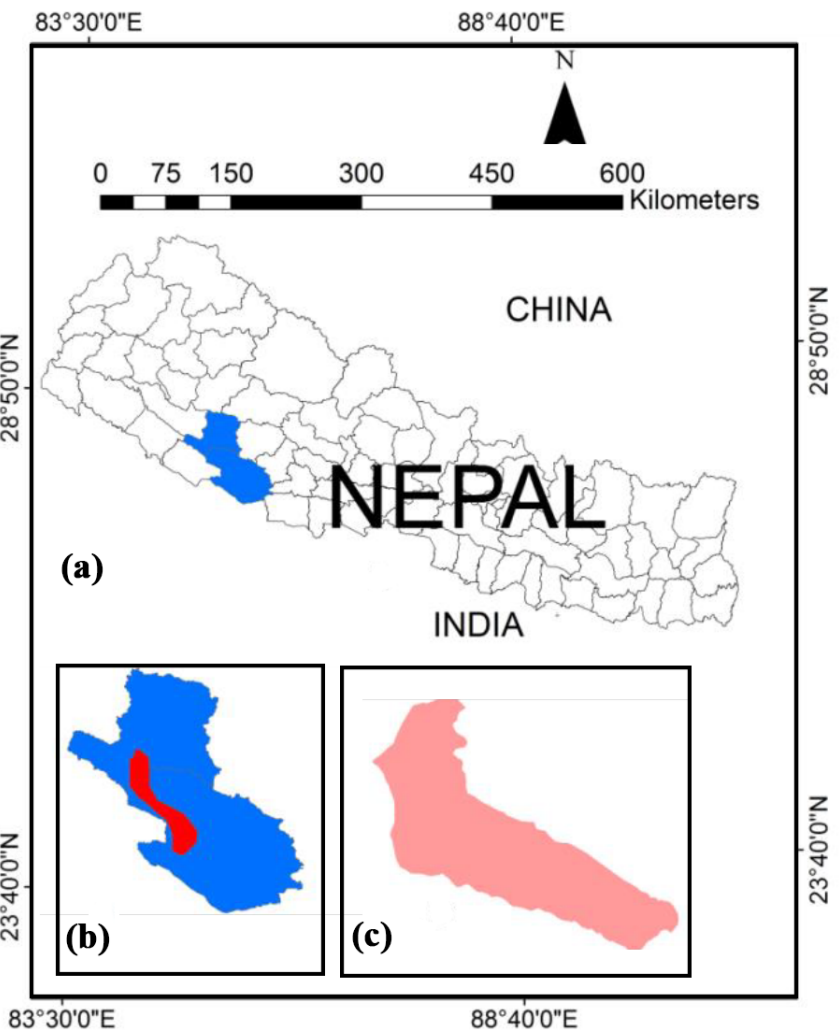

Fig. 1: (a) Map of Nepal, (b) Dang and Salyan Districts showing study area, and (c) Map of the Malai catchment

of Nepal (Figs. 1 and 2). It is a tributary of the Babai River. The catchment size of the Malai River is $78 \mathrm{sq} . \mathrm{km}$, having min. Elv. $484 \mathrm{~m}$ and max. Elv. $1210 \mathrm{~m}$ (Fig. 3). Altogether 67 gullies are present in the area, and 6 are sub catchment having area more than $4 \mathrm{sq} . \mathrm{km}$. The gullies without debris flow are 31 and with debris flow are 36 (Fig. 2). The minimum area of debris flow channel is $1957 \mathrm{sq}$. $\mathrm{m}$ and maximum area is 242760 sq. $\mathrm{m}$. The total area of debris channel is $1.178 \mathrm{sq} . \mathrm{km}$ and area of channel without debris flow is $0.56 \mathrm{sq} . \mathrm{km}$. The total area of main channel of the Malai River is $1.81 \mathrm{sq} . \mathrm{km}$. The maximum slope of study area is 58 degrees and maximum area is covered by the slope 10-30 degrees (Fig. 4).

The climate of study area is sub-tropical. The winter is very cold and summer is very hot. The rainfall is heavy and occasionally intense during rainy season. The average annual rainfall over the period 1986-2017 is in the range of 1400-3000 $\mathrm{mm}$. More than 80 percent of rainfall occurs in rainy season. In the year 2015, the maximum 24 hours rainfall was recorded as $236.6 \mathrm{~mm}$ that was the highest rainfall within 24 hours since 2000. The total rainfall in three months (June, July and August) in 2015 was $1397.6 \mathrm{~mm}$. The rainfall pattern in every part of study area is same.

\section{GEOLOGICAL SETTING}

The Siwalik zone is located between two major Thrusts; Main Boundary Thrust (MBT) and Main Frontal Thrust (MFT),

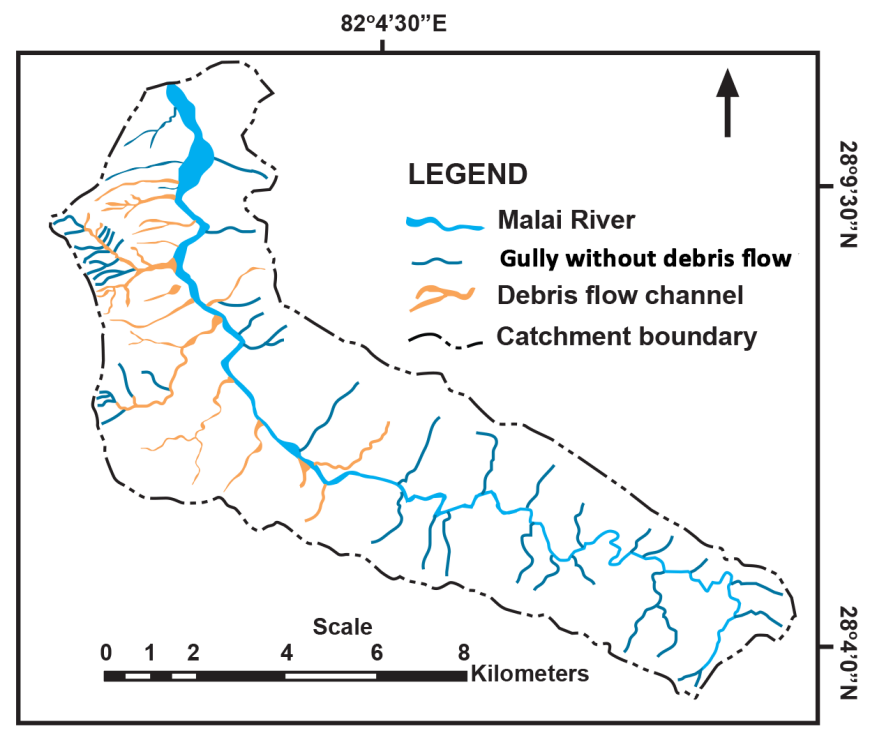

Fig. 2 Drainage map with debris flow channel of the Malai River catchment

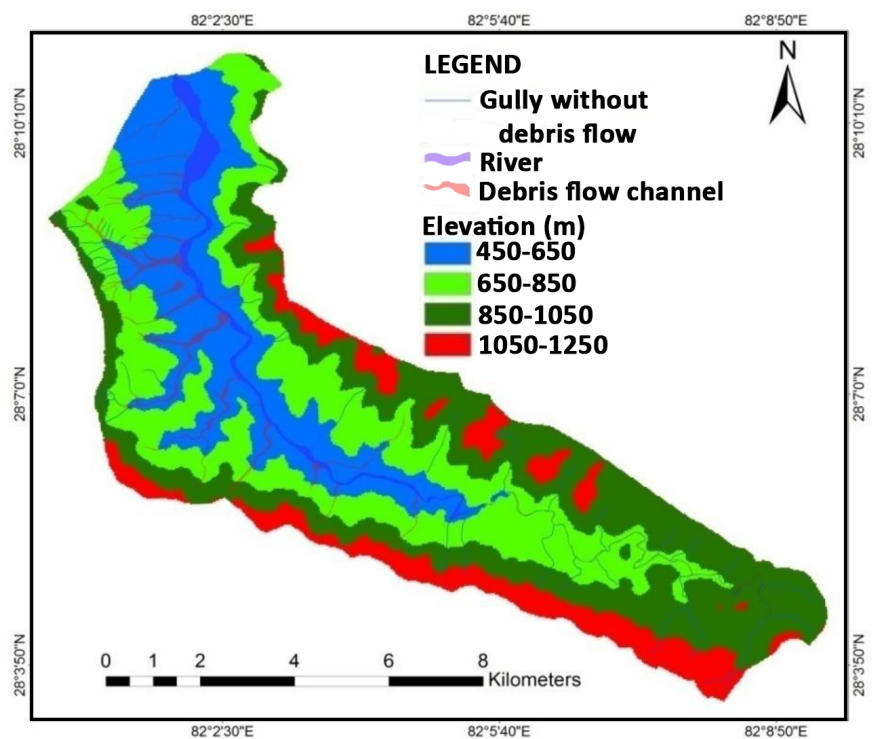

Fig. 3: Elevation map of the Malai River Catchment

and is bounded by Indo-Gangetic Plain at South and the Lesser Himalayan zone at North. The Siwalik Group in the study area is lithologically divided into three units; Lower Siwalik, Middle Siwalik and Upper Siwalik in ascending order. The study area consists of two major thrusts; the Malai Thrust and the Babai Thrust. The Lower Siwalik consists of very fine to fine grained greenish grey sandstone interbedded with variegated mudstone where the proportion of mudstone dominates. The Middle Siwalik consists of medium to coarse grained thickly bedded sandstone with dark grey mudstone. The Upper Siwalik consists of well sorted pebble and cobble conglomerate with thin layer of mudstone and sandstone. The conglomerates beds are mostly clay bonded. 


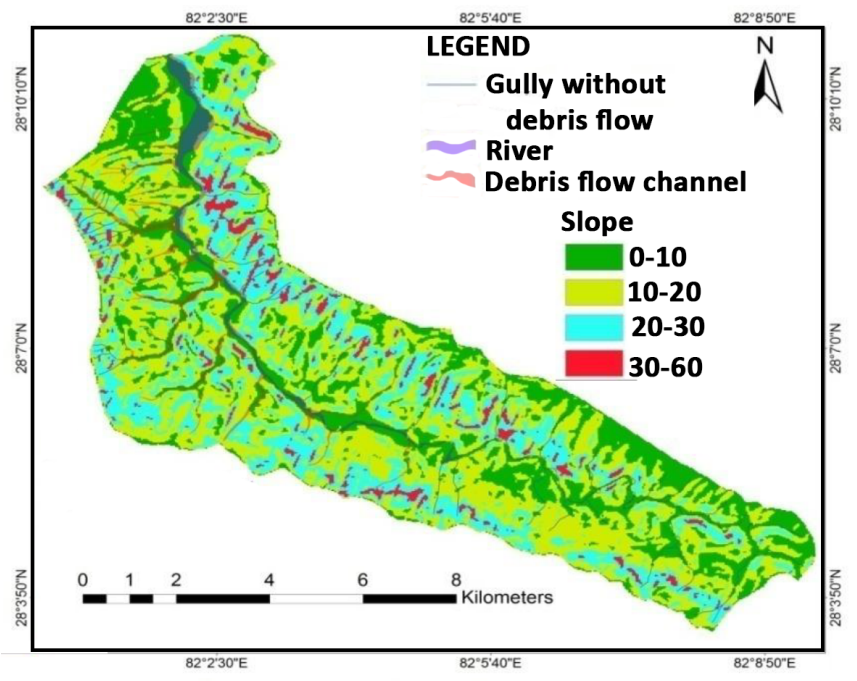

Fig. 4: Slope map of the Malai River catchment

\section{METHODS}

DEM based data were used for analysis. The total length and area of debris flow were identified from the Google earth free online satellite image. Every gully with and without debris flow was traced out by polygon. The catchment area of each debris flow was measured by drawing polygon. Total area of gully and area of debris flow of each gully were identified. The debris flow inventory was prepared in the Google earth and verified in the field. Data that had been prepared in the Google earth were obtained in the Arc GIS and used to prepared a map. The origin of debris flow was studied in the field and the causative factors like slope geometry, curvature, geology and nature of gullies were studied in the field. The thrust zone was identified. Debris flow mechanism and occurrence were related with the hanging wall and foot wall of the thrust. The sub catchment of debris flow was sub divided in to source area such as transporting and depositional area. In the field, the major role of topographic factor for the debris flow occurrence was focused so that only the sensitive gully for debris flow occurrence could be selected. For the analysis of topographic factors, the certain topographical parameters, such as: watershed area, channel length, elevation different, average gradient of stream, form factor, percentage of basin area with slope angle as described by Li et al. (2015) were selected.

The form factor $\mathrm{F}$ was calculated using the equation developed by Li et al. (2015) as:

$$
\mathrm{F}=\mathrm{A} / \mathrm{L} 2
$$

where, $\mathrm{A}$ is catchment size of each debris flow and $\mathrm{L}$ is the length of stream in the catchment. According to Chang (2007), under the same conditions, a watershed with a large form factor has a higher likelihood to generate debris flows.

The average gradient of a stream $(\mathrm{J})$ was calculated as the ratio of the elevation difference between the slope of origin of the stream and the slope of outlet of the catchment to the stream length. For the calculation of the gradient, the stream can be divided into a number of sections, for each of which an average gradient of the stream is calculated (Eq. 2).

Average gradient of stream in the formation area of debris flow was calculated by using equation after $\mathrm{Li}$ et al. (2015) as:

$$
\mathrm{J}=\left[\operatorname{SUM}\left(\mathrm{H}_{\mathrm{i}-1}+\mathrm{H}_{\mathrm{i}}\right) \mathrm{L}_{\mathrm{i}}-2 \mathrm{H}_{\mathrm{o}} \mathrm{L}\right] / 1000 \mathrm{~L}^{2}
$$

where, $\mathrm{J}$ is average gradient of stream, Hi is elevation of upper part of each section and $\mathrm{H} 0$ is elevation of lowest part of each stream. $\mathrm{Li}$ is the stream length of each section and $\mathrm{L}$ is the total length of debris flow channel.

The ratio of area of each catchment to area of potential slope (S) was measured by using DEM of $30 \mathrm{~m}$ resolution prepared by digitized topo map of 1:25,000 scales. The ratio of area of each slope class and area of catchment is denoted as 'S":

$$
\mathrm{S}=\mathrm{A} / \mathrm{a} \text {. }
$$

where, $\mathrm{A}=$ area of catchment and $\mathrm{a}=$ area of potential slope.

Gradient or slope of catchment plays vital role for the formation of debris flow. In general, Flow velocity of water is higher in the steep slope. Landslide and rock fall are very common phenomena in the slope $>400$. During heavy rainfall in the rainy season, the water having high velocity carries the deposited materials and slope cutting materials with it. So, slope is another important factor to occur debris flow.

Catchment size also determines the amount of debris flow sediment. Larger the catchment area, larger the sediments likely to be provided by landslide or any other mass movement (Li et al., 2015). The large catchment area collects large amount of water during heavy rainfall and flows with high speed towards downstream that causes higher discharge in the channel and debris flow.

Topographical factor $(\mathrm{T})$ is the factor obtained from the combination of form factor, catchment size, average gradient of stream and ratio of slope class area and catchment area as after equation of $\mathrm{Li}$ et al. (2015):

$$
\mathrm{T}=\mathrm{FJS}(\mathrm{A} / \mathrm{a})^{0.2}
$$

Every topographical factor was analysed by using linear regression. The relationship between each factor with debris flow occurrence was identified.

\section{RESULTS}

Among the 67 gullies, debris flow event was present only in 36 gullies. But only 20 major gullies with debris flow were selected for study. The debris flow is found higher number in conglomerate bed in comparison with sandstone and mudstone (Fig. 5). 


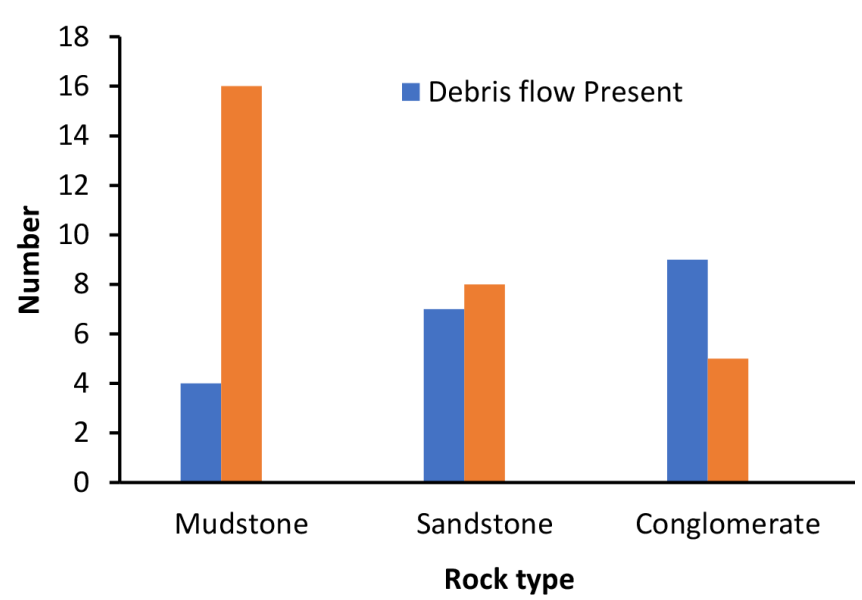

Fig. 5: The bar diagram shows the debris flow present and absent in the associated rock type

Most of the landslides and debris flows (Fig. 3) are concentrated in the hanging wall of the Malai thrust (Fig. 6). The thrust separates the Middle and the Upper Siwaliks hanging wall from the Lower Siwalik foot wall.

Five major factors were considered for the debris flow analysis. Form factor (F), slope percentage (S), average gradient of stream $(\mathrm{J})$ and topographical factor $(\mathrm{T})$ (Table 1). It is considered that higher the form factor higher the discharge of water and higher the possibility of debris flow. Similarly, higher the catchment area, higher will be the flood possibility. The higher value of topographical factor is considered as the higher possibility of debris flow.

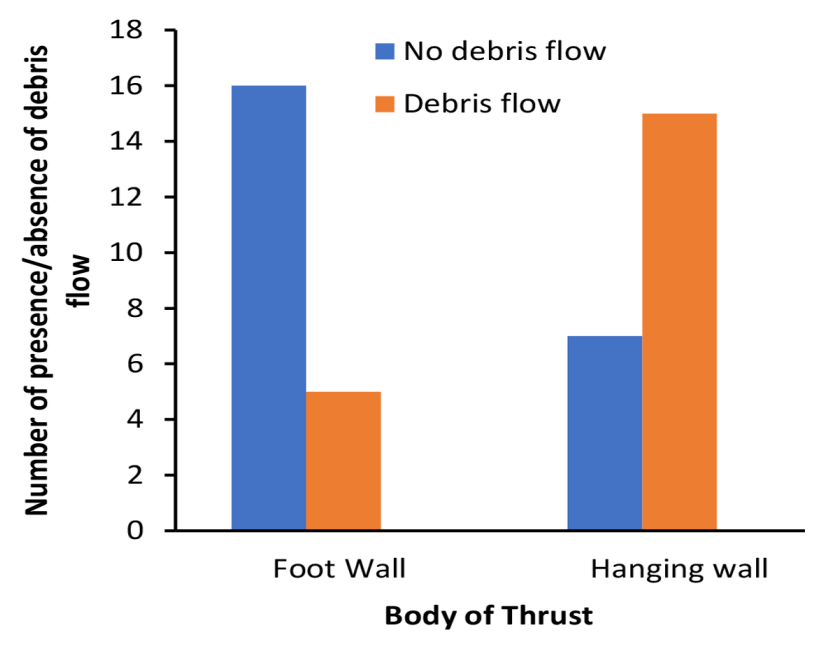

Fig. 6: Number of debris flow present and absent in the foot wall and hanging wall of the Malai thrust

Relationship between different factors was identified by using general linear model. The relation between form factor and area slope percentage, form factor and catchment size, form factor and average gradient, average gradient and area percentage of each debris flow gullies were analysed.

It was assumed that there should be positive relation between each factor. But the relation was not satisfactory to conclude the result. Every debris flow occurred during the intense rainfall. The gullies of same topography without debris flow and with debris flow were compared. For the further verification and identification of gully-type debris flow mechanism, geological study was done.

Table 1: Geological and topographical factors of debris flow channel, Malai Khola watershed

\begin{tabular}{|c|c|c|c|c|c|c|c|c|c|}
\hline SN & Rock & $\mathrm{Fr}$ & $\mathrm{A} 0$ & A & $\mathrm{L}$ & $\mathrm{F}$ & $\mathrm{J}$ & $\mathrm{S}$ & $\mathrm{T}$ \\
\hline 1 & Sandstone & MS & 0.020 & 0.690 & 2.17 & 0.15 & 0.110 & 0.4 & 0.006 \\
\hline 2 & Sandstone & MS & 0.140 & 0.481 & 1.63 & 0.18 & 0.160 & 0.58 & 0.014 \\
\hline 3 & Sandstone & MS & 0.027 & 0.356 & 1.84 & 0.11 & 0.100 & 0.55 & 0.005 \\
\hline 4 & Sandstone & MS & 0.006 & 0.033 & 0.40 & 0.21 & 0.181 & 0.65 & 0.012 \\
\hline 5 & Sandstone & MS & 0.063 & 0.641 & 5.64 & 0.02 & 0.360 & 0.63 & 0.004 \\
\hline 6 & Mudstone & $\mathrm{LS}$ & 0.028 & 0.410 & 1.42 & 0.20 & 0.241 & 0.62 & 0.025 \\
\hline 7 & Mudstone & Ls & 0.026 & 0.134 & 1.30 & 0.08 & 0.310 & 0.68 & 0.011 \\
\hline 8 & Mudstone & LS & 0.242 & 2.220 & 6.90 & 0.05 & 0.420 & 0.7 & 0.016 \\
\hline 9 & Mudstone & $\mathrm{LS}$ & 0.037 & 0.077 & 0.79 & 0.12 & 0.189 & 0.74 & 0.010 \\
\hline 10 & Sandstone & MS & 0.060 & 0.280 & 2.00 & 0.07 & 0.287 & 0.72 & 0.011 \\
\hline 11 & Sandstone & MS & 0.234 & 3.800 & 5.00 & 0.15 & 0.223 & 0.58 & 0.025 \\
\hline 12 & Conglomerate & US & 0.107 & 2.900 & 4.45 & 0.15 & 0.123 & 0.64 & 0.006 \\
\hline 13 & Conglomerate & US & 0.069 & 0.047 & 1.74 & 0.01 & 0.381 & 0.80 & 0.003 \\
\hline 14 & Conglomerate & US & 0.028 & 0.068 & 0.70 & 0.14 & 0.221 & 0.82 & 0.015 \\
\hline 15 & Conglomerate & US & 0.018 & 0.284 & 1.00 & 0.28 & 0.120 & 0.76 & 0.020 \\
\hline 16 & Conglomerate & US & 0.026 & 0.250 & 1.50 & 0.11 & 0.090 & 0.74 & 0.006 \\
\hline 17 & Conglomerate & US & 0.027 & 1.010 & 2.35 & 0.18 & 0.264 & 0.86 & 0.024 \\
\hline 18 & Conglomerate & US & 0.022 & 0.220 & 1.60 & 0.09 & 0.368 & 0.76 & 0.018 \\
\hline 19 & Conglomerate & US & 0.002 & 0.050 & 0.23 & 0.96 & 0.420 & 0.77 & 0.171 \\
\hline 20 & Conglomerate & US & 0.032 & 0.140 & 1.13 & 0.12 & 0.112 & 0.55 & 0.005 \\
\hline
\end{tabular}


To verify the $\mathrm{T}$ factors, the values of $\mathrm{T}$ factors of the gullies with and without debris flow were calculated and listed in Table 1. Gullies having larger debris flow event have T value greater than 0.01 and gullies having small debris flow event have $\mathrm{T}$ value less than 0.01 . $\mathrm{T}$ values of gullies without debris flow were less than 0.001 .

\section{DISCUSSION}

Debris flow caused by long duration or short-term intense rainfall may be generated from landslide or several soil erosion. Takahashi (2000) studied about debris flow and concluded that landslide, bedrock erosion and natural dam destruction are three major causes to induce debris flow. In present study, slidetriggered debris flows were found negligible. Most of the debris flows occurred due to erosion of weathered bed rock and old colluvium during heavy runoff. The study area consists of weak and fragile Cenozoic, alternate layer of sedimentary rocks like mudstone, sandstone and conglomerate. The sandstone and conglomerate beds are found very weak and easily erodible in the study area.

It is found that most of the debris flow was occurred in 2015 AD. Maximum annual and 24-hour rainfall was recorded in the very same year. An earthquake of 7.8 ML was occurred in the same year. The debris flows are concentrated near and along the Malai Thrust. The earthquake may have loosened the slope material making them more unstable (Li et al., 1015).

Topographical factors were compared with geological factors. The form factor was found greater at the hanging wall than at the foot wall of the Malai Thrust. Most of the debris flows are at the hanging wall of thrust and those flows were occurred in the monsoon of 2015 after the Gorkha earthquake. The thrust can be one of major responsible factors for debris flow occurrence. Lithologically, the Middle and the Upper Siwaliks are found potential for debris flow occurrence. Mostly the gullies are formed due to continuous erosion. Erosion in the Upper Siwalik was found notable due to clay and loose cement binding conglomerate. Therefore, gully-type debris flow is common in the Upper Siwalik. The Middle Siwalik of study area consists of alternate beds of thick sandstone and thin mudstone (Bhandari and Dhakal, 2018). The weak and fragile mudstone erodes with flow of water mostly in steep slope, where sandstone beds get low support and detache from original beds generating landslides (Tamrakar and Yokota, 2008). The landslide mass flows through gully and converts in to debris flow at time of intense or continuous rainfall.

The topographical factor alone could not justify the occurrence of gully-type debris flow. If we see the result of debris flow occurrence and non-occurrence in the hanging wall and foot wall of the thrusts, debris flow occurrence in the hanging wall is higher than that in the foot wall, whereas opposite is true for non-occurrence of debris flow. The values of form factor, topographical factor, average gradient of gulley and area slope percentage are higher in hanging wall of thrust and these factors are higher in sandstone of the Middle Siwalik and Conglomerate of the Upper Siwalik.

\section{CONCLUSION}

The rainfall conditions in the studied catchments were roughly identical during the large rainfall event. A topographic factor $\mathrm{T}$ is proposed as a single topographical indicator, which may be used as an indicator of the formation of gully-type debris flows. The major topographic factors related with the development of debris flows are the catchment form factor, the gradient of the stream channels, and the size of the catchments. The topographical factor $\mathrm{T}$ is a combination of these three factors and the area percentage of the catchment of terrain slopes between 100-600. Initiation of debris flow is also controlled by the local geological factor. Finally, the conclusion is made the Probability of debris flow to occur increases with increase of topographic factors in the thrust zone at weak sedimentary rocks. It can be concluded that the topographical and geological factors are mainly responsible for gully-type debris flow in the study area.

\section{REFERENCES}

Akgun, A., Dag, S., and Bulut, F., 2008, Landslide susceptibility mapping for a landslide-prone area (Findikli, NE of Turkey) by likelihood frequency ratio and weighted linear combination models. Environ Geol., v. 54, pp. 1127-1143.

Bhandary, B.P. and Dhakal, S., 2018, Lithological Control on Landslide in the Babai Khola Watershed, Siwaliks Zone of Nepal. American Journal of Earth Sciences. Vol. 5, No. 3, pp. 54-6.

Catani, F., Casagli, N., Ermini, L., Righini, G., and Menduni, G., 2005, Landslide hazard and risk mapping at catchment scale in the Arno River basin. Landslides, v. 2, pp. 329-342.

Chang, T.C. and Chao, R.J., 2006, Application of backpropagation networks in debris flow prediction. Eng Geol., v. 85 , pp. 270-280.

Chang, T.C., 2007, Risk degree of debris flow applying neural networks. Nat Hazards, v. 42, pp. 209-224.

Chang, T.C. and Chien, Y.H., 2007, The application of genetic algorithm in debris flows prediction, Environ Geol., v 53, pp. 339-347.

Huang, J., vanAsch, T.W.J., Wang, C., and Li, Q., 2019, Study on the combined threshold for gully-type debris ?ow early warning. Nat. Hazards Earth Syst. Sci., 19, pp. 41-51. https://doi.org/10.5194/nhess-19-41-2019

Hua-yong, N., 2015, Experimental study on initiation of gullytype debris flow based on artificial rainfall and channel runoff. AGRIS, Springer-Verlag, v. 73, no. 10, pp. 6213-6227.

Kean, J.W., McCoy, S.W., Tucker, G.E., Staley,. DM., and Coe, J.A., 2013, Runoff-generated debris flows: observations 
and modeling of surge initiation, magnitude, and frequency. J Geophys Res Earth surf., v. 118, pp. 2190-2207.

Lan, H.X., Zhou, C.H., Wang, L.J., Zhang, HY., and Li, R.H., 2004, Landslide hazard spatial analysis and prediction using GIS in the Xiaojiang watershed, Yunnan, China. Eng Geol., v. 76, pp. 109-128.

Lee, S. and Pradhan, B., 2007, Landslide hazard mapping at Selangor, Malaysia using frequency ratio and logistic regression models. Landslides, v. 4, pp. 33-41.

Li, L., Yu B., Zhu, Y., Chu, S., and Wu, Y., 2015, Topographical factors in the formation of gully-type debris flows in Longxi River catchment, Sichuan, China. Environ Earth Sci, v. 73, pp. 4385-4398. DOI 10.1007/s12665-0143722-7.

Lin, J.Y., Hung, J.C., and Yang, M.D., 2002, Assessing debrisflow hazard in a watershed in Taiwan. Eng Geol., v. 66, pp. 295-313.

Liu, C., Dong, J., Peng, Y., Huang, H., 2009, Effects of strong ground motion on the susceptibility of gully type debris flows. Eng Geol., v. 104, pp. 241-253.

Mei, H., Xiewen, H., and Kai, H., 2018, Comparative study between debris flow of wide-gentle and narrow-steep channel based on numerical simulation and prevention measures. Journal of Nepal Geological Society, 2018, vol. 55 (Sp. Issue), pp. 167-172

Ranjan, K.D., Shuichi, H., Atsuko, N., Minoru, Y., Takuro, M., and Katsuhiro, N., 2004, GIS-based weights-of-evidence modelling of rainfallinduced landslides in small catchments for landslide susceptibility mapping. Environ Geol., v. 54, pp. 311-324.

Stiny, J., 1910, Die Muren (Debris flows). Wagnerschen Univ., Buchhandlung, Innsbruck, Austria. English translation, EBA Consult., Vancouver, Canada, 199p.

Takahashi, T., 2007, Debris Flow Mechanics, Prediction and Countermeasures. Florence: Florence, KY, USA: CRC Press.

Takahashi, T., 2000, Initiation and flow of various types of debris flow. In: Wieczorek G.F. and Naeser N.D. (eds), Debris-flows hazard mitigation: mechanics prediction and assessment. Balkema, Rotterdam, pp. 15-25.

Tamrakar, N.K. and Yokota, S., 2008, Types and processes of slope movements along East-West Highway, Surai Khola area, Mid-Western Nepal Sub-Himalaya. Bulletin of the Department of Geology, Tribhuvan University, Kathmandu, Nepal, v. 11, pp. 1-4.

Tiranti, D., Bonetto, S., and Mandrone, G., 2008, Quantitative basin characterisation to refine debris-flow triggering criteria and processes: an example from the Italian Western Alps. Landslides, v. 5, pp. 45-57.

Tunusluoglu MC, Gokceoglu C, Nefeslioglu HA, Sonmez H (2008) Extraction of potential debris source areas by logistic regression technique: a case study from Barla, Besparmak and Kapi mountains (NW Taurids, Turkey). Environ Geol 54:9-22

Van Dine DF (1985). Debris flow and debris torrents in the Southern Canadian Cordillera. Can Geotech J 22:44-68 